\section{IMPROVED GUM HEALTH IN 95\% OF PATIENTS}

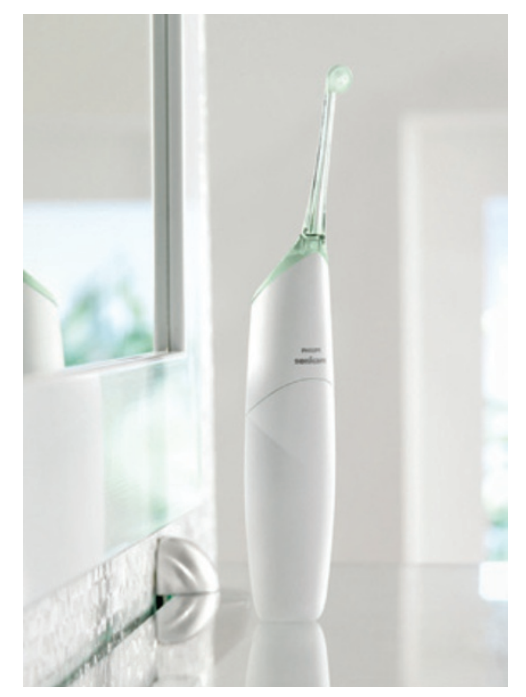

Dental hygienists $(\mathrm{n}=340)$ noted improved gum health in 95\% of their patients with mild to moderate gingivitis after using the Philips Sonicare AirFloss for two months.

The Philips Sonicare AirFloss is an electronic hand-held interdental cleaning device; in the overall 60 -day study, patients used the device with mouthwash instead of water in the reservoir.

The hygienists also reported a reduction in their patients' gingival inflammation and bleeding, and $88 \%$ a significant improvement in interproximal health with an average of 73\% reduction in bleeding sites. Overall 96\% showed improved oral hygiene when they returned to the practice for a check-up at the end of the study.

The Philips Sonicare AirFloss removes five times more interproximal plaque than brushing alone by propelling rapid bursts of air and micro droplets of water or mouthwash between teeth to remove plaque and bacteria. The device has an auto-burst function which provides a continuous stream of automatic pulses to clean between the teeth in less than 60 seconds via an angled nozzle.

The US dental hygienists involved in the study believed that $87 \%$ of their patients would continue to use AirFloss regularly.

www.sonicare.com

\title{
ADVICE ON COMPLETING YOUR PENSIONS REPORT
}

30 June 2014 is the deadline for practice owners to submit the NHS Pensions annual reconciliation report (ARR). PFM Townends, a team of specialist dental accountants, can provide advice on how to complete it.

The ARR is the practice owner's opportunity to confirm the pensionable pay allocation for the practice and is vitally important to ensure you and your associates maintain accurate NHS Pension Scheme records.

Here is how the ARR is calculated:

- The Pensionable Pay 'ceiling' for the practice is the gross amount of the NHS contract multiplied by $43.9 \%$

- Associates' pensionable pay figure is what they actually get paid rather than any calculation involving the UDA value

- Practice owners' pensionable pay figure is the total 'ceiling' amount less the following:

- Total of all associates" pensionable pay

- Actual pay for any dentists working at the practice who are already in receipt of their NHS pension
- Actual pay for any associates who operate through a limited company.

The remaining amount may be claimed by the practice owner as their own pensionable pay, but doesn't have to be. An increase in pensionable pay could mean practice owners breach the new HMRC lifetime and annual limits for pensions. Furthermore, practice owners must have sufficient earned income (net profits/salary/dividends) to justify the level of pension contributions that they can claim tax relief on.

For information and advice visit www.pfmdental.co.uk.

\section{BESPOKE DENTAL AND MEDICAL CABINETRY}

For over 35 years now, Tavom has distinguished itself as one of the leading providers of bespoke dental and medical cabinetry in the industry.

The team at Tavom understand that every room within a dental practice has a well-defined purpose, and it is important that each of these areas function with optimal efficacy. They also have all the experience and skills to ensure your new practice meets all your specifications, and a range of colours and finishes are available to help you create a design totally unique to you.
Supplied by Tavom UK, all cabinetry is crafted of the most durable materials for maximum longevity, and styles incorporate ergonomics for optimal comfort and aesthetics for both staff and patient alike.

With absolute dedication to first-class customer service, open communication and flexible working times, you can also rely on the team at Tavom UK to make the whole process as easy and stress-free as possible.

For a full catalogue of products, or to find out more, visit www.tavomuk.com.

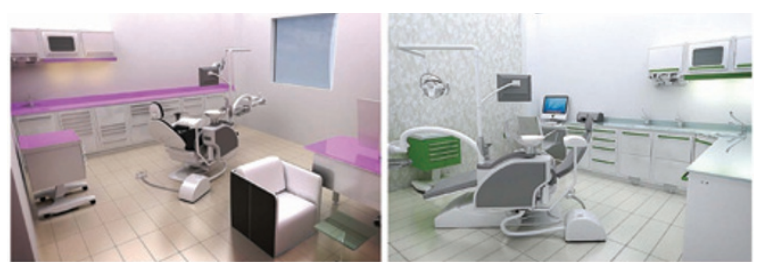

\section{OUICK, RELIABLE LAB WORK EVERY TIME}

Sparkle Dental Labs have recently welcomed two new members of staff to the customer services team. They are also soon to be joined by ten new dental technicians, ensuring that Sparkle can meet the growing demand for expert craftsmanship.

Sparkle Dental Labs keep you informed every step of the way so that you'll know which technician is looking after your order and when your product is ready for dispatch and free delivery. They will also send all new restorations with patient statement certificates both for your peace of mind and to ensure compliance with GDC regulations.

Sparkle work hard to create the products you need, when you need them. So, if you are looking for a British dental laboratory that you can trust, contact Sparkle Dental Labs today on 0800138 6255, email customerservice@ sparkledentallabs.com or visit www.sparkledentallabs.com. 